Article

\title{
Evaluation of Parameters for Estimating the Postmortem Interval of Skeletal Remains Using Bovine Femurs: A Pilot Study
}

\author{
Midori Nagai ${ }^{1}$, Koichi Sakurada ${ }^{2, *}$, Kazuhiko Imaizumi ${ }^{3}$, Yoshinori Ogawa ${ }^{3}$, Motohiro Uo ${ }^{4}$, \\ Takeshi Funakoshi ${ }^{1}$ and Koichi Uemura ${ }^{1}$ \\ 1 Department of Forensic Medicine, Tokyo Medical and Dental University, 1-5-45 Yushima, Bunkyo-ku, \\ Tokyo 113-8519, Japan; naglegm@tmd.ac.jp (M.N.); funakoshi.legm@tmd.ac.jp (T.F.); \\ kuemura.legm@tmd.ac.jp (K.U.) \\ 2 Department of Forensic Dentistry, Tokyo Medical and Dental University, 1-5-45 Yushima, Bunkyo-ku, \\ Tokyo 113-8510, Japan \\ 3 Second Biology Section, First Department of Forensic Science, National Research Institute of Police Science, \\ 6-3-1 Kashiwanoha, Kashiwa, Chiba 277-0882, Japan; imaizumi@nrips.go.jp (K.I.); \\ y-ogawa@nrips.go.jp (Y.O.) \\ 4 Department of Advanced Biomaterials, Tokyo Medical and Dental University, 1-5-45 Yushima, Bunkyo-ku, \\ Tokyo 113-8510, Japan; uo.abm@tmd.ac.jp \\ * Correspondence: sakurada.fde@tmd.ac.jp; Tel./Fax: +81-3-5803-4387
}

Received: 13 November 2020; Accepted: 7 December 2020; Published: 9 December 2020

\begin{abstract}
The postmortem interval (PMI) of victims is a key parameter in criminal investigations. However, effective methods for estimating the PMI of skeletal remains have not been established because it is determined by various factors, including environmental conditions. To identify effective parameters for estimating the PMI of skeletal remains, we investigated the change in bone focusing on the amount of DNA, element concentrations, and bone density that occurred in the bone samples of bovine femurs, each maintained under one of five simulated environmental conditions (seawater, freshwater, underground, outdoors, and indoors) for 1 year. The amount of extracted mitochondrial DNA (mtDNA; 404 bp fragment) decreased over time, and significant DNA degradation $(p<0.01)$, as estimated by a comparison with amplification results for a shorter fragment (128 bp), was detected between 1 month and 3 months. Eleven of 30 elements were detected in samples by inductively coupled plasma optical emission spectrometry, and $\mathrm{Na}$ and Ba showed significant quantitative differences in terms of environmental conditions and time $(p<0.01)$. This preliminary study suggests that the level of DNA degradation determined by real-time polymerase chain reaction and element concentrations determined by inductively coupled plasma optical emission may be useful indices for estimating the PMI of victims under a wide range of environmental conditions. However, this study is a limited experimental research and not applicable to forensic cases as it is. Further studies of human bone with longer observation periods are required to verify these findings and to establish effective methods for PMI estimation.
\end{abstract}

Keywords: bone density; DNA degradation; element concentration; postmortem interval; skeletal remains; inductively coupled plasma optical emission spectrometry

\section{Introduction}

In forensic science, the postmortem interval (PMI) of victims is one of the most important factors for criminal investigations. In particular, in cases of skeletal remains, the PMI becomes very difficult to estimate because soft tissues decrease substantially or completely. Many researchers 
have focused on the development of novel methods, including infrared (IR)/Raman microscopic imaging techniques [1,2], inductively coupled plasma optical emission spectroscopy (ICP-OES) [3], or microcomputed tomography $(\mu \mathrm{CT})[4,5]$. In addition, combinations of techniques have been reported, such as the combined use of different physicochemical methods [6], luminol and microscopic techniques to screen bones before the use of radiocarbon dating [7], ultraviolet (UV)-induced fluorescence and $490 \mathrm{~nm}$ induced fluorescence [8], and $\mu \mathrm{CT}$, mid-infrared microscopic imaging, and energy-dispersive X-ray mapping [9]. Molecular biology approaches have been used to evaluate the relationships between environmental insults and DNA degradation [10-13]. Because DNA is often highly fragmented [14,15], mitochondrial DNA could be more useful than nuclear DNA $[15,16]$.

Element analyses are often used in the field of archeology and have recently been applied in forensic science to examine the degree of bone degradation. Walden et al. used ICP-OES to measure bone degradation [3]. Gallelo et al. [17] compared elemental compositions between bones and the environment. Because elements in compact bone are not easily affected by the environment when the bone density is high, elemental compositions and bone density should be measured at the same time. Considering the structure of compact bone, rich in narrow ducts, it is necessary to establish alternative methods for obtaining the precise density. $\mu \mathrm{CT}$ is a non-destructive method used to observe the detailed three-dimensional structure of small specimens. After analyses by $\mu \mathrm{CT}$, samples can be used for other tests, such as DNA or elemental analyses. When only a small bone fragment is available, $\mu \mathrm{CT}$ might be useful. We applied this method to precisely measure the density of compact bone with the aim of establishing an effective indicator of the PMI.

Changes in bone exposed to various environmental conditions have not been evaluated from the viewpoints of biological, chemical, and physical properties over long periods of time. Therefore, in this study, the changes in bone were investigated to find effective parameters for estimating the PMI of skeletal remains on the basis of analyses of DNA quantity, element concentrations, and bone density in bovine compact bones, each exposed to one of five environmental conditions (i.e., seawater, freshwater, underground, outdoor, and indoor conditions) for 1 year.

\section{Materials and Methods}

\subsection{Bone Sample Preparation}

A femur was taken from a 30 month old cow. After removing soft tissues, including the periosteum, the bone shaft was cut into two parts along the bone axis using an electric cast cutter (Stryker Corporation, Kalamazoo, MI, USA) and the bone marrow was removed. Bone shafts were divided into eight parts by vertical and horizontal cuts. These parts were then cut into pieces weighing approximately $1 \mathrm{~g}$ each. All of these bone pieces included both the periosteum and the bone marrow sides. Fan-shaped bone pieces were obtained, and two horizontally cut surfaces were smoothed by slicing off their thin surfaces with a precision cutting machine (aqra PRECISO CL40; JEOL Ltd., Tokyo, Japan) and diamond disc (Horico Dental Hopf, Ringleb \& Co. GmbH \& Cie, Berlin, Germany) with cooling water. The specimens were washed with neutral detergent and Milli-Q ultrapure water (Merck KGaA, Darmstadt, Germany). After drying at room temperature, they were stored at $-30{ }^{\circ} \mathrm{C}$ until use. The specimens were analyzed almost a week after they were removed from the investigated conditions. The control was analyzed at the same time after 3 days.

\subsection{Environmental Conditions}

Five environmental conditions were simulated-immersion in seawater, immersion in freshwater, buried underground, outside, and indoors-considering the conditions in the area surrounding Tokyo, Japan, particularly soil type. The seawater was prepared by dissolving powdered artificial seawater (Nihon Kaisui, Tokyo, Japan) in distilled water. For the freshwater treatment, Mount Fuji mineral water was used (Suntory, Osaka, Japan). Each specimen was immersed in $50 \mathrm{~mL}$ of liquid in a disposable test tube. These liquids were exchanged once per week throughout the experimental period 
to keep them as fresh as possible. Most of the soil in the Tokyo area is a mixture of red and black soil. Therefore, we mixed non-heat-treated red and black soil in a 1:1 ratio for the underground condition. Soil type is a key parameter in forensic analyses. The black soil was a Japan-specific soil called "Kurobokudo", which results from field burning, volcanic ash, and humus [18]. For outdoor conditions, an airy site with a roof in Tokyo was used. The temperature in Tokyo was $16.8^{\circ} \mathrm{C}$, on average, and was highest $\left(39^{\circ} \mathrm{C}\right)$ in July in the summer and lowest $\left(-4^{\circ} \mathrm{C}\right)$ in January in the winter in 2018 . To simulate indoor conditions, specimens were separately placed in a laboratory with a temperature of $25^{\circ} \mathrm{C}$. The water immersion and soil burial conditions were also simulated in this room. Bone samples prepared as described above were used as controls. Five bone specimens were each placed in a $50 \mathrm{~mL}$ tube and exposed to the conditions for various durations ( 3 days, 1 week, 1 month, 3 months, 6 months, and 1 year). The tubes were placed upright on a tube rack and covered with a plastic film to avoid contamination with insects and dust. This treatment also kept soils moist throughout the experiment. Overall, samples from five environmental conditions (seawater, freshwater, underground, outside, and indoors) at six time points (3 days, 1 week, 1 month, 3 months, 6 months, and 1 year) and a control were investigated. We prepared two sets of specimens for each environmental condition (one for DNA quantitation and elemental analysis, and the other for density analysis). All experiments were started at the same time in January 2018 and ended in January 2019.

Collected specimens were washed with a neutral detergent using a sponge, followed by several washes with ultrapure water. After drying samples under a plastic hood at room temperature for $24 \mathrm{~h}$, parts for DNA analyses were pulverized using a Multi-beads shocker (MB1200; Yasui Kikai Co. Ltd., Osaka, Japan) at $2000 \mathrm{rpm}$ for $20 \mathrm{~s}$ and at $3000 \mathrm{rpm}$ for $10 \mathrm{~s}$ or $20 \mathrm{~s}$ until pulverized completely. After $24 \mathrm{~h}$ of drying at room temperature, these pulverized samples were kept at $-30{ }^{\circ} \mathrm{C}$ until use. The specimens were analyzed almost a week after they were removed from the investigated conditions. The control was analyzed at the same time after 3 days.

\subsection{DNA Extraction and Quantification}

Approximately $0.2 \mathrm{~g}$ of bone powder was transferred into $50 \mathrm{~mL}$ tubes. Decalcification was performed using $30 \mathrm{~mL}$ of $0.5 \mathrm{M}$ ethylenediaminetetraacetic acid (EDTA) at $56{ }^{\circ} \mathrm{C}$ for $24 \mathrm{~h}$. To remove EDTA, the powder was washed with ultrapure water five times by centrifugation at $3000 \mathrm{rpm}$ for $5 \mathrm{~min}$. The powder was digested with $25 \mu \mathrm{L}$ of Proteinase K (20 mg/mL; Takara Bio Inc., Shiga, Japan) and $1000 \mu \mathrm{L}$ of Proteinase K buffer (Takara Bio Inc.; http://catalog.takara-bio.co.jp/PDFS/9034_DS_j.pdf) at $56{ }^{\circ} \mathrm{C}$ for $24 \mathrm{~h}$. Proteinase $\mathrm{K}$ buffer contained 0.01 M Tris- $\mathrm{HCl}$ (pH 7.8), $0.01 \mathrm{M}$ EDTA, and 0.5\% sodium dodecyl sulfate. The tube was not shaken during the processing of EDTA and Proteinase K. DNA was extracted using the QIAamp DNA Mini Kit (Qiagen Benelux B.V., Venlo, Netherlands) according to the manufacturer's instructions. DNA extracts were adjusted to $50 \mu \mathrm{L}$ with buffer AE (Qiagen Benelux B.V.).

Two primer sets targeting the $16 \mathrm{~S}$ ribosomal RNA (rRNA) region of bovine mitochondrial DNA (mtDNA) were used (Table 1). The target products were $128 \mathrm{bp}$ [19] and $404 \mathrm{bp}$, and the degree of DNA degradation was estimated by comparing amplification. The primers for the longer target were designed using Primer 3 Plus (https://primer3plus.com/), and the specificity was confirmed using Primer-BLAST (https://www.ncbi.nlm.nih.gov/tools/primer-blast/). Real-time PCR amplification was performed using a Thermal Cycler Dice Real Time System III (Takara Bio Inc.) according to the manufacturer's instructions. TB Green Premix Ex Taq II Tli RNaseH Plus (Takara Bio Inc.) was used for amplification according to the manufacturer's instruction. The total volume of PCR reaction was $25 \mu \mathrm{L}$ and the template DNA was $2 \mu \mathrm{L}$. For the $128 \mathrm{bp}$ target, reaction conditions were $95^{\circ} \mathrm{C}$ for $30 \mathrm{~s}$, followed by 40 cycles at $95^{\circ} \mathrm{C}$ for $5 \mathrm{~s}$ and $60{ }^{\circ} \mathrm{C}$ for $30 \mathrm{~s}$. For the $404 \mathrm{bp}$ target, cycling conditions were set to $95^{\circ} \mathrm{C}$ for $30 \mathrm{~s}$, followed by 40 cycles at $95^{\circ} \mathrm{C}$ for $5 \mathrm{~s}$ and $60^{\circ} \mathrm{C}$ for $40 \mathrm{~s}$. The extraction blank control was the negative control for each condition and PCR blanks were also tested. DNA extracts were not diluted. Samples were quantified in triplicate. To generate a calibration curve, serial dilutions of the bovine mtDNA positive control (Promega KK, Madison, WI, USA: Code No. MO-COW 15000/Lot 
No. PCW180818) were used. Total DNA quantitation was performed using the NanoDrop One Spectrophotometer (ThermoFisher Scientific, Waltham, MA, USA) with $2 \mu \mathrm{L}$ of each extracted DNA solution according to the manufacturer's instructions.

Table 1. Primers designed in this study.

\begin{tabular}{|c|c|c|}
\hline \multirow{2}{*}{ PCR Product Size (bp) } & \multicolumn{2}{|c|}{ Primer Sequences $\left(5^{\prime}-3^{\prime}\right)$} \\
\hline & Forward & Reverse \\
\hline 404 & CTTGTATGAATGGCCGCACG & TGATGGTGCAACCGCTATCA \\
\hline 128 & AACCATTAAGGAATAACAACAA & AAATCACTCTATCGCTCATTG \\
\hline
\end{tabular}

\subsection{Elemental Analysis by ICP-OES}

Qualitative and semiquantitative analyses of 30 elements were performed as a preliminary test to select appropriate elements for the study. Bone powder obtained from the control, seawater, freshwater, and underground specimens after 6 months $(n=1)$ was weighed, and $0.1 \mathrm{~g}$ of each sample was hydrolyzed with nitric acid. After drying, pyrolysis was performed with perchloric acid and nitric acid. After drying to leave several microliters, sample solutions were prepared immediately by the addition of $20 \mathrm{~mL}$ of diluted nitric acid. The elements $\mathrm{Li}, \mathrm{Be}, \mathrm{B}, \mathrm{Na}, \mathrm{Mg}, \mathrm{Al}, \mathrm{Si}, \mathrm{P}, \mathrm{K}, \mathrm{Ca}, \mathrm{Ti}, \mathrm{V}, \mathrm{Cr}, \mathrm{Mn}, \mathrm{Fe}, \mathrm{Co}, \mathrm{Ni}$, $\mathrm{Cu}, \mathrm{Zn}, \mathrm{As}, \mathrm{Se}, \mathrm{Sr}, \mathrm{Zr}, \mathrm{Mo}, \mathrm{Ag}, \mathrm{Cd}, \mathrm{Sn}, \mathrm{Sb}, \mathrm{Ba}$, and $\mathrm{Pb}$ were semi-quantitated by the single inspection method with the standard solution (Multi-Element Calibration Standard 3,4, and 5, PerkinElmer, Inc., Waltham, MA, USA and Custom Assurance Standard XSTC-22, SPEX CertiPrep, Metuchen, NJ, USA) using ICPS-8100 (Shimadzu Corporation, Kyoto, Japan).

On the basis of this preliminary analysis, elements were chosen for precise quantitation. Specimens from the seawater, freshwater, and underground conditions after 6 months and 1 year, as well as the control $(n=3)$, were used for further quantitative analyses, following the protocol used for the preliminary test. The concentrated solutions obtained from specimens were diluted with $20 \mathrm{~mL}$ of diluted nitric acid and applied to the analyses. The calibration curve was prepared from serially diluted standard solutions of $\mathrm{Na}, \mathrm{Zn}$, and $\mathrm{Ba}$ (Kanto Chemical Co., Inc., Tokyo, Japan). The elemental analysis by ICP-OES was supported by the analysis service (Shimadzu Corporation, Kyoto, Japan).

\subsection{Bone Density Measurement by Micro X-Ray CT}

Control specimens $(n=5)$ and the specimens obtained from seawater, freshwater, underground, outdoor, and indoor conditions at the periods of 6 months and 1 year $(n=5$ each) were scanned with the micro X-ray CT system (InspeXio SMX-225CT FPD FR; Shimadzu Corporation). Scanning parameters for cone-beam CT were $200 \mathrm{kV}$ and $70 \mu \mathrm{A}$, with the default rotation and collection frequency optimized for observing light metals. The slice thickness was $0.020 \mathrm{~mm}$. The scanned data were analyzed using VGStudio Max 3.2 (Volume Graphics GmbH, Heidelberg, Germany) by three-dimensional volume rendering methods, and volumes in $\mathrm{mm}^{3}$ were obtained. All procedures were performed by a single researcher, and the samples were analyzed in random order. Bone density was calculated on the basis of the volume and mass measured before the scan.

\subsection{Statistical Analysis}

Statistical analyses were conducted using Statcel (The Useful add-in Forms on Excel, 4th ed.). The interquartile range (IQR) was checked and outliers were omitted before statistical analyses. To check normality and homoscedasticity, F-tests were performed. Student's $t$-test, one-way analysis of variance with Turkey-Kramer post hoc tests, and Dunnett's test were used. The level of significance was set to $1 \%$. 


\section{Results}

\subsection{Visual Observation of Bone Samples in Five Environmental Conditions}

Figure 1 shows images of the specimens subjected to conditions for 1 year. They were photographed after washing and drying. The control was yellowish-white (Figure 1a). The colors of the specimens in seawater (Figure 1b) and freshwater (Figure 1c) were nearly the same as that of the control, while the specimens in outdoor and indoor conditions (Figure 1d,e) were whitish. The underground specimens (Figure 1f,g) showed variable coloration, including brownish with many dark brown spots and wholly light brown.

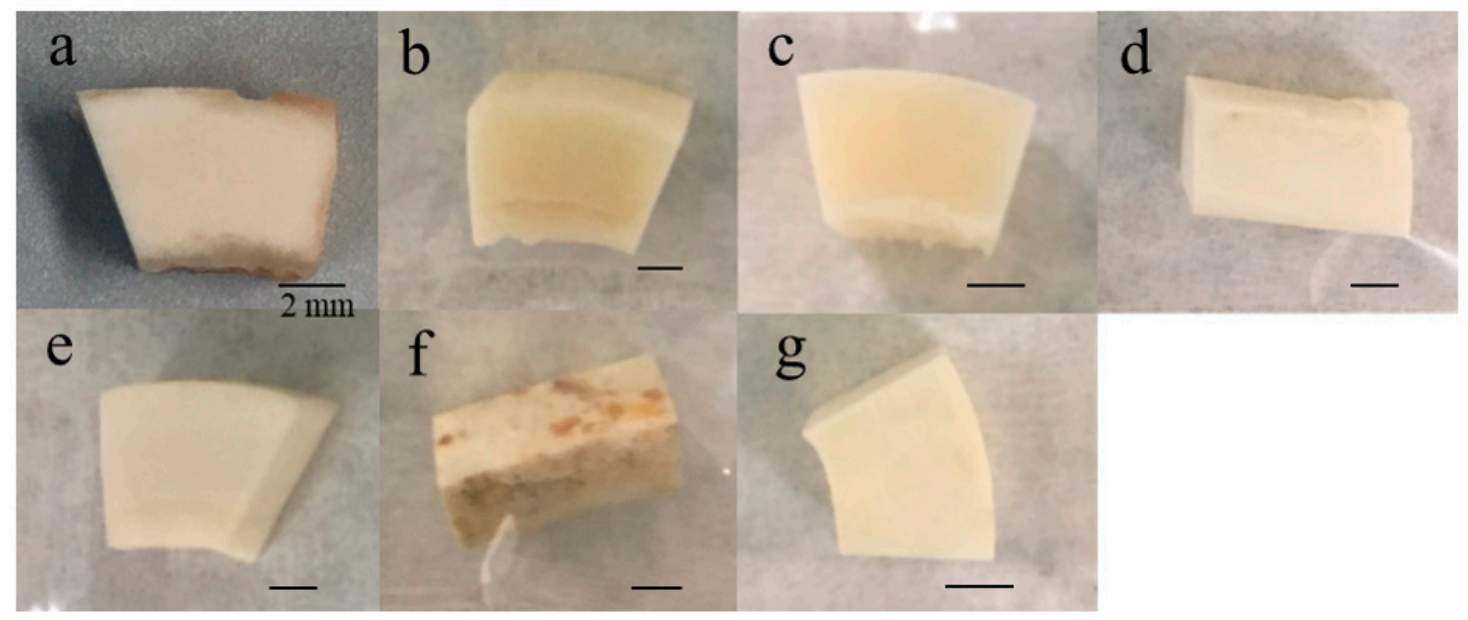

Figure 1. Bone samples maintained under five environmental conditions for 1 year: (a) control, (b) seawater, (c) freshwater, (d) outdoors, (e) indoors, and (f,g) underground.

\subsection{DNA Quantitation of Bones Exposed to Various Environmental Conditions}

DNA quantitation results obtained by real-time PCR for the $404 \mathrm{bp}$ target are summarized in Figure 2. DNA quantity decreased over time in most conditions, except indoor conditions. DNA quantities for specimens in seawater and freshwater at 1 week were significantly lower than that of the control $(p<0.01)$. The DNA quantity of the underground specimen became significantly lower than that of the control at just 3 days $(p<0.01)$. DNA quantities for indoor specimens did not decrease significantly over a 1 year period and were significantly higher than that of the control at 3 days and 1 month $(p<0.01)$. Comparing environmental conditions, although decreases in DNA quantities occurred the earliest in underground conditions among the four conditions except indoor, they showed the same extent of decrease at 1 year.

Figure 3 shows differences in DNA quantities among five conditions at 1 month and 1 year. DNA quantities were significantly lower $(p<0.01)$ for the specimens subjected to freshwater and underground conditions and significantly higher for indoor conditions $(p<0.01)$ than for the control at 1 month. DNA quantities were significantly lower $(p<0.01)$ compared with the control at 1 year under all conditions. The DNA quantity for samples in seawater, outdoor, and indoor conditions decreased between 1 month and 1 year.

Figure 4 summarizes the degree of DNA degradation over time, as estimated by the difference in amplification of the two PCR targets (404 bp and $128 \mathrm{bp}$ ) by real-time PCR. Although the decreases in DNA quantities showed similar trends for the short (128 bp) and long (404 bp) targets in all five environmental conditions, DNA quantities were significantly higher for the long target at 3 days in seawater $(p<0.05)$, and similar trends were seen at 3 days in freshwater and indoor conditions. Moreover, DNA quantities were significantly lower for the long target at 3 months in seawater $(p<0.05)$, as well as 1 month and 3 months in underground and outdoor conditions $(p<0.05$ or $p<0.01)$. Significant differences between conditions were not observed after 6 months. 
Figure 5 summarizes the results for total DNA quantitation using a spectrophotometer. DNA quantities from specimens in seawater, freshwater, and underground conditions were significantly lower than that in the control $(p<0.01)$ at 3 months, 1 week, and 3 days, respectively. For samples in outdoor conditions, DNA quantity did not change significantly over time. In indoor conditions, the DNA quantity was significantly higher than that in the control $(p<0.01)$ at 3 days and 6 months, and it was significantly lower than that in the control $(p<0.05)$ at 1 year. Compared with real-time PCR, spectrophotometer showed higher DNA quantities (for example, in an underground sample, real-time PCR: $0.18 \pm 0.06 \mathrm{ng} / \mu \mathrm{L}$; spectrophotometer: $23.95 \pm 6.31 \mathrm{ng} / \mu \mathrm{L})$.
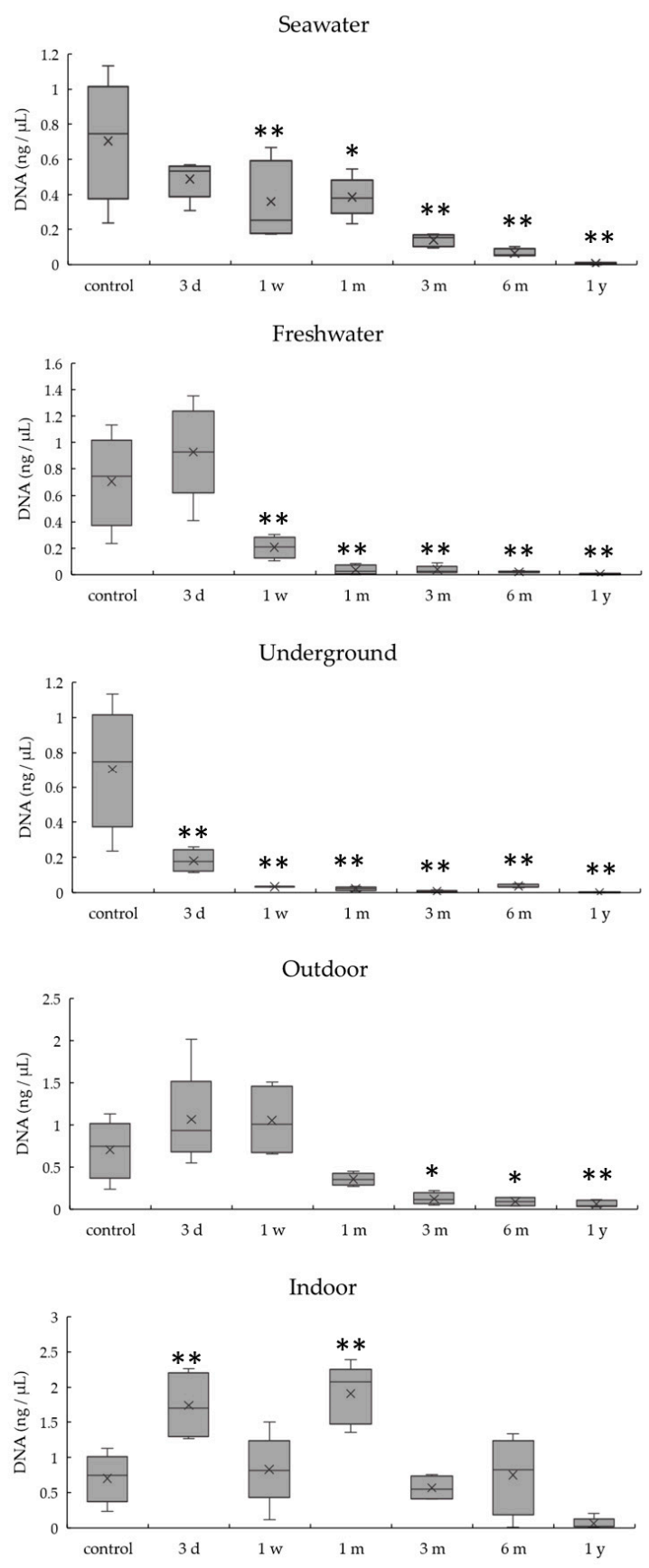

Figure 2. DNA quantitation of a $404 \mathrm{bp}$ target by real-time PCR in bones exposed to five environmental conditions for 1 year. Data are presented as means and standard deviations. ${ }^{*} p<0.05$ vs. control, ** $p<0.01$ vs. control. 


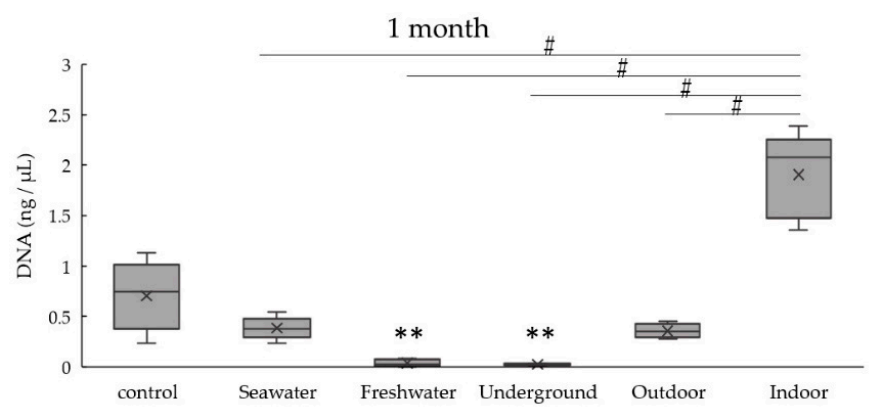

1 year

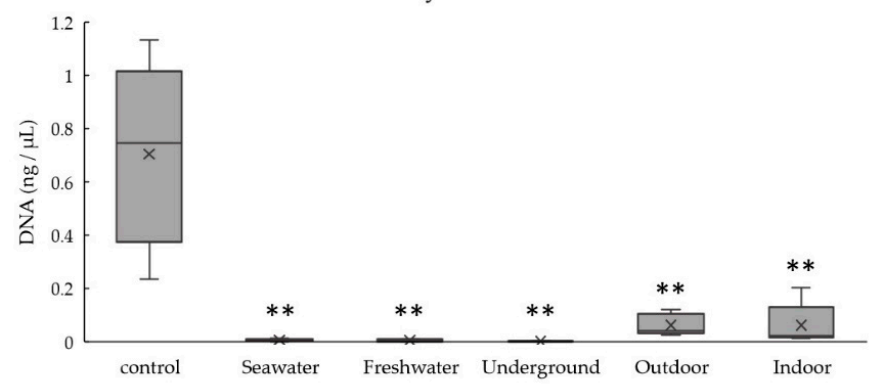

Figure 3. Differences in the amount of DNA between the five environmental conditions at 1 month and 1 year. Data are presented as means and standard deviations. ${ }^{* *} p<0.01$ vs. control, ${ }^{*} p<0.01$.
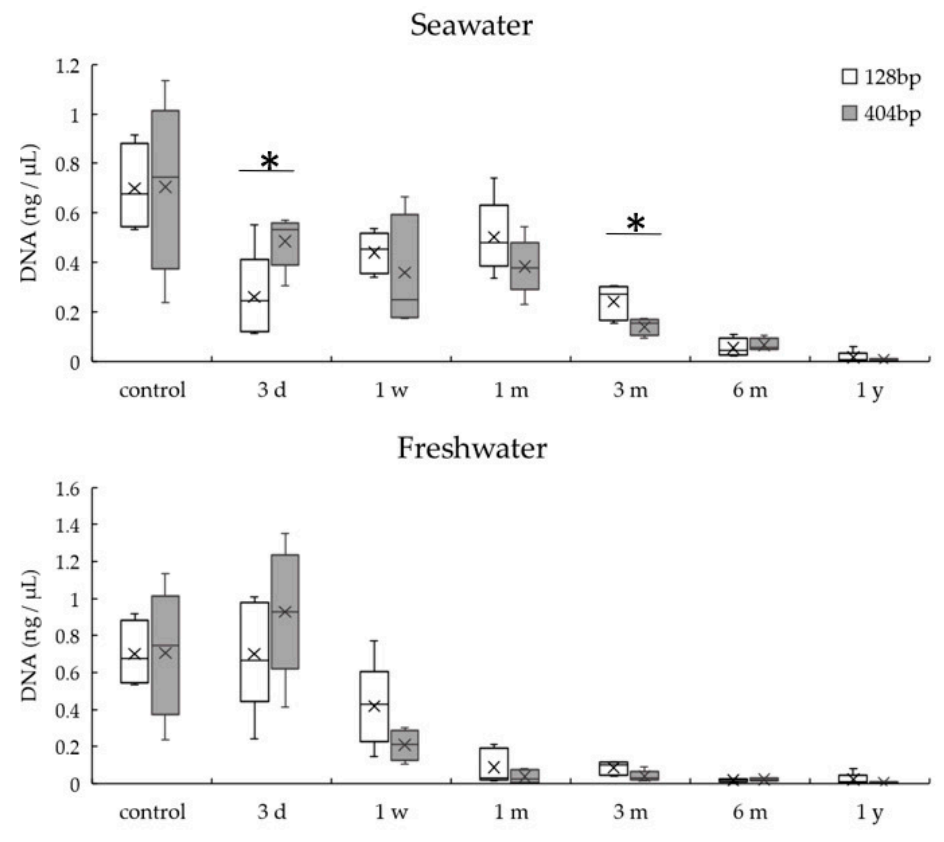

Underground

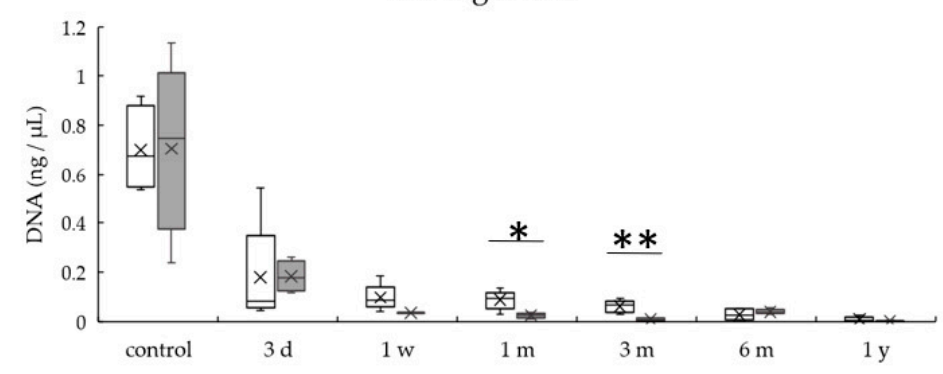

Figure 4. Cont. 

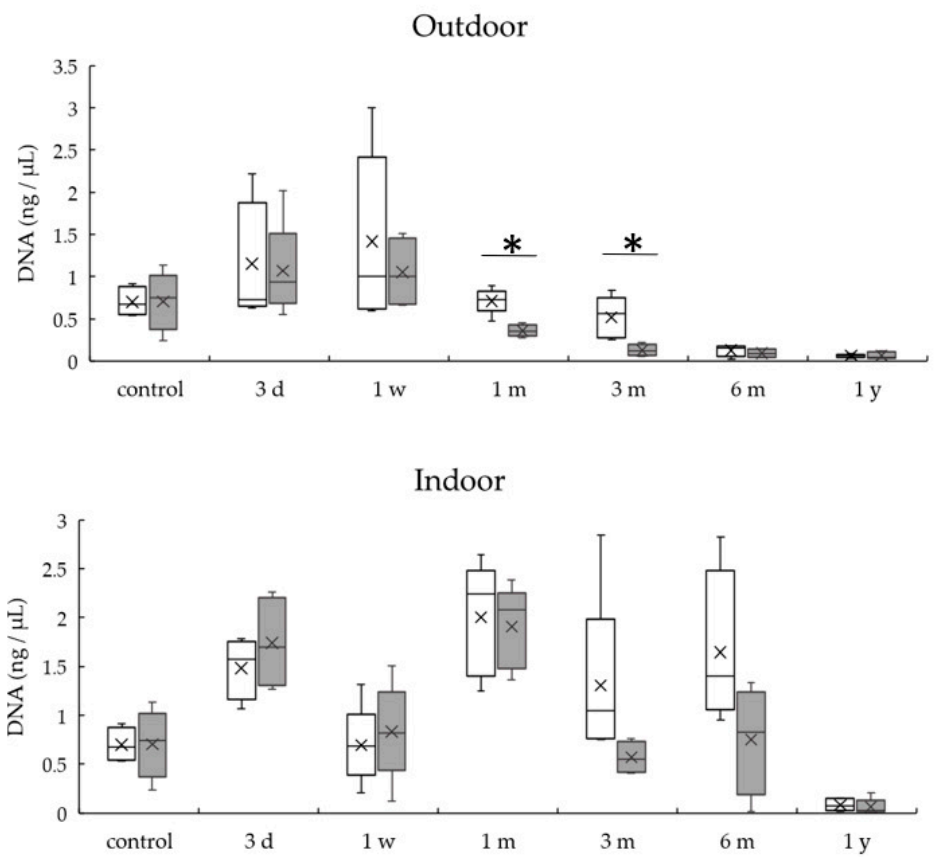

Figure 4. DNA degradation over time based on the amplification of $404 \mathrm{bp}$ and $128 \mathrm{bp}$ fragments by real-time PCR (404 bp vs. 128 bp). ${ }^{*} p<0.05,{ }^{* *} p<0.01$.
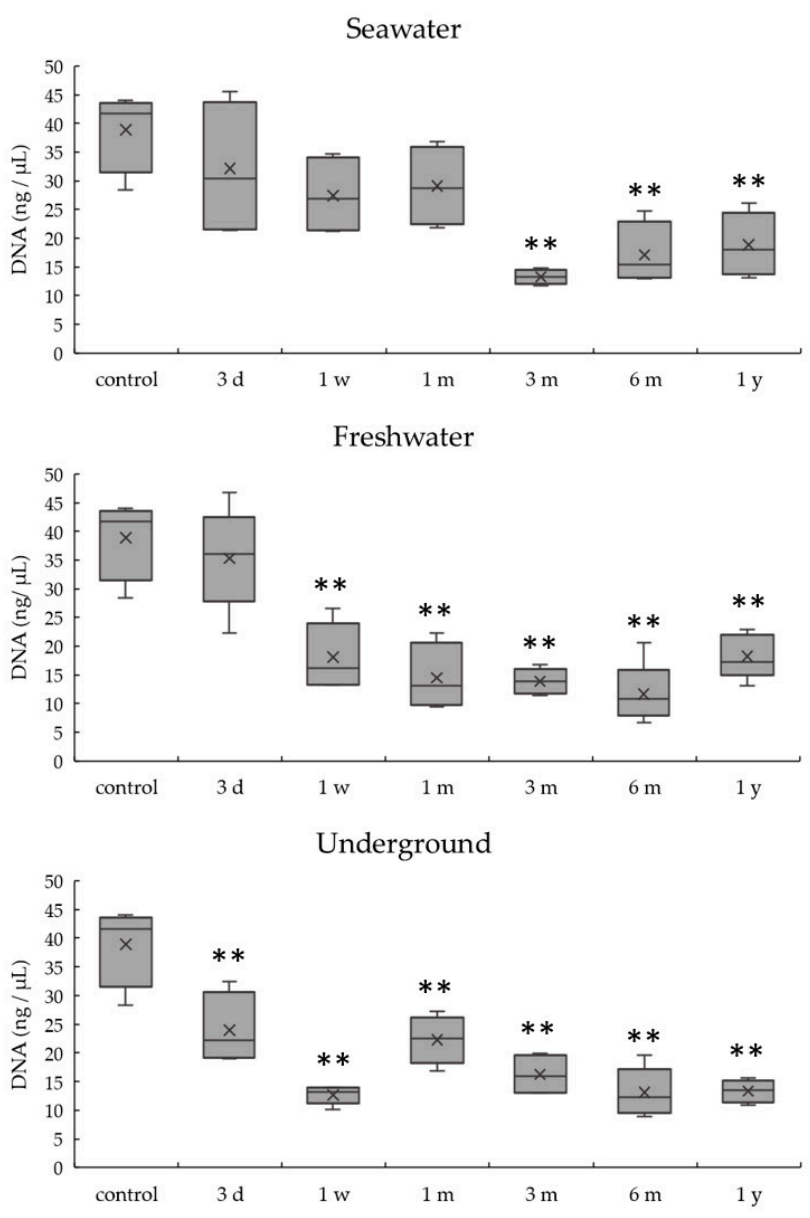

Figure 5. Cont. 

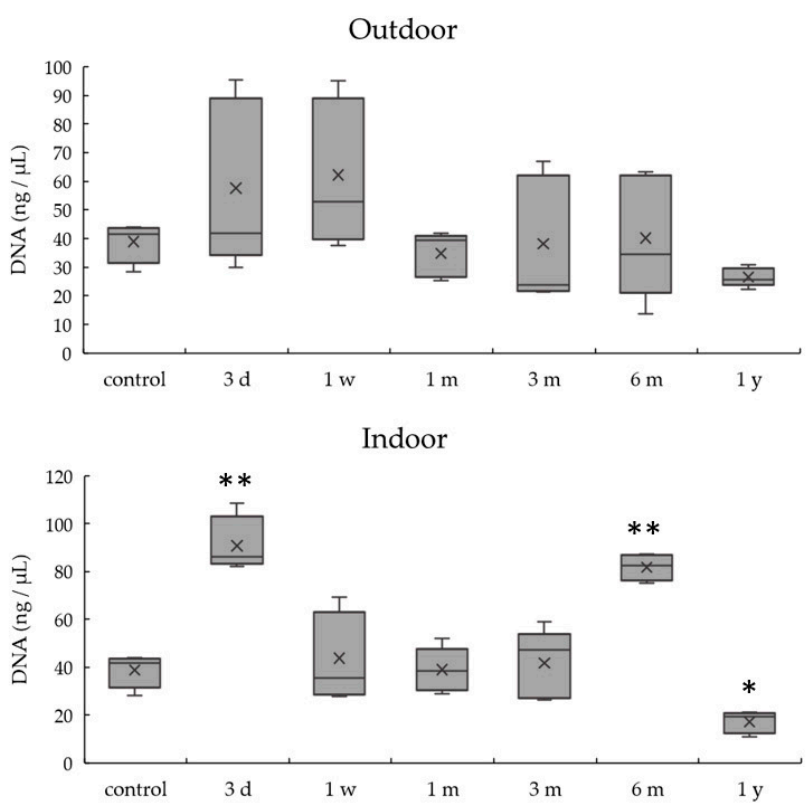

Figure 5. DNA quantitation by the absorbance method under five environmental conditions for 1 year. Means and standard deviations are presented. ${ }^{*} p<0.05$ vs. control, ${ }^{* *} p<0.01$ vs. control.

\subsection{Elemental Analysis by ICP-OES}

Qualitative and semiquantitative analyses of 30 elements in pulverized specimens were performed by ICP-OES. Analyzed samples were the control, seawater, freshwater, and underground specimens after 6 months $(n=1)$. In a preliminary test, 11 of 30 elements were detected by comparisons with standard solutions (Table 2). Among these, $\mathrm{Na}, \mathrm{Zn}$, and Ba showed variations among conditions. As such, these three elements were quantitatively analyzed in the specimens subjected to seawater, freshwater, and underground conditions ( 6 months and 1 year, $n=3$ each), as well as in control samples. The results are summarized in Figure 6. For specimens at 6 months and 1 year in freshwater conditions, the Na content was significantly lower than that in the control $(p<0.01)$. The Na content did not differ between 6 months and 1 year. $\mathrm{Zn}$ did not show a significant change in any conditions. Ba showed a significant decrease in all environments, except underground, at 6 months $(p<0.01)$. In underground conditions, there was a significant difference in the Ba content between 6 months and 1 year $(p<0.05)$, but no difference was found in the specimens maintained in seawater and freshwater.

Table 2. Qualitative and semiquantitative analyses of 30 elements by ICP-OES.

\begin{tabular}{|c|c|c|c|c|c|}
\hline \multirow{3}{*}{ Element } & \multicolumn{4}{|c|}{ Estimated Concentration } & \multirow{2}{*}{ Detection Limi } \\
\hline & Control & Seawater & Freshwater & Underground & \\
\hline & $(\mu \mathrm{g} / \mathrm{g})$ & $(\mu \mathrm{g} / \mathrm{g})$ & $(\mu \mathrm{g} / \mathrm{g})$ & $(\mu \mathrm{g} / \mathrm{g})$ & $(\mu \mathrm{g} / \mathrm{g})$ \\
\hline $\mathrm{Li}$ & $\mathrm{ND}^{*}$ & ND & ND & ND & 10 \\
\hline $\mathrm{Be}$ & ND & ND & ND & ND & 0.2 \\
\hline $\mathrm{B}$ & ND & 60 & ND & ND & 20 \\
\hline $\mathrm{Na}$ & 5000 & 7000 & 4000 & 6000 & 100 \\
\hline $\mathrm{Mg}$ & 5000 & 5000 & 4000 & 5000 & 2 \\
\hline $\mathrm{Al}$ & ND & ND & ND & ND & 10 \\
\hline $\mathrm{Si}$ & ND & ND & ND & ND & 20 \\
\hline $\mathrm{P}$ & 100,000 & 100,000 & 100,000 & 100,000 & 20 \\
\hline K & ND & ND & ND & ND & 400 \\
\hline $\mathrm{Ca}$ & 200,000 & 200,000 & 200,000 & 200,000 & 200 \\
\hline $\mathrm{Ti}$ & ND & ND & ND & ND & 40 \\
\hline $\mathrm{V}$ & ND & ND & ND & ND & 4 \\
\hline
\end{tabular}


Table 2. Cont.

\begin{tabular}{|c|c|c|c|c|c|}
\hline \multirow{3}{*}{ Element } & \multicolumn{4}{|c|}{ Estimated Concentration } & \multirow{2}{*}{ Detection Limi } \\
\hline & Control & Seawater & Freshwater & Underground & \\
\hline & $(\mu \mathrm{g} / \mathrm{g})$ & $(\mu \mathrm{g} / \mathrm{g})$ & $(\mu \mathrm{g} / \mathrm{g})$ & $(\mu \mathrm{g} / \mathrm{g})$ & $(\mu \mathrm{g} / \mathrm{g})$ \\
\hline $\mathrm{Cr}$ & 20 & ND & ND & 5 & 4 \\
\hline $\mathrm{Mn}$ & 3 & ND & ND & ND & 1 \\
\hline $\mathrm{Fe}$ & 300 & ND & ND & ND & 20 \\
\hline Co & ND & ND & ND & ND & 10 \\
\hline $\mathrm{Ni}$ & ND & ND & ND & ND & 10 \\
\hline $\mathrm{Cu}$ & ND & ND & ND & ND & 10 \\
\hline $\mathrm{Zn}$ & 60 & 70 & 90 & 60 & 10 \\
\hline As & ND & ND & ND & ND & 40 \\
\hline Se & ND & ND & ND & ND & 40 \\
\hline $\mathrm{Sr}$ & 200 & 200 & 100 & 200 & 0.2 \\
\hline $\mathrm{Zr}$ & ND & ND & ND & ND & 4 \\
\hline Mo & ND & ND & ND & ND & 10 \\
\hline $\mathrm{Ag}$ & ND & ND & ND & ND & 10 \\
\hline $\mathrm{Cd}$ & ND & ND & ND & ND & 4 \\
\hline Sn & ND & ND & ND & ND & 20 \\
\hline $\mathrm{Sb}$ & ND & ND & ND & ND & 20 \\
\hline $\mathrm{Ba}$ & 100 & 70 & 80 & 100 & 2 \\
\hline $\mathrm{Pb}$ & ND & ND & ND & ND & 40 \\
\hline
\end{tabular}

* ND: not detected.
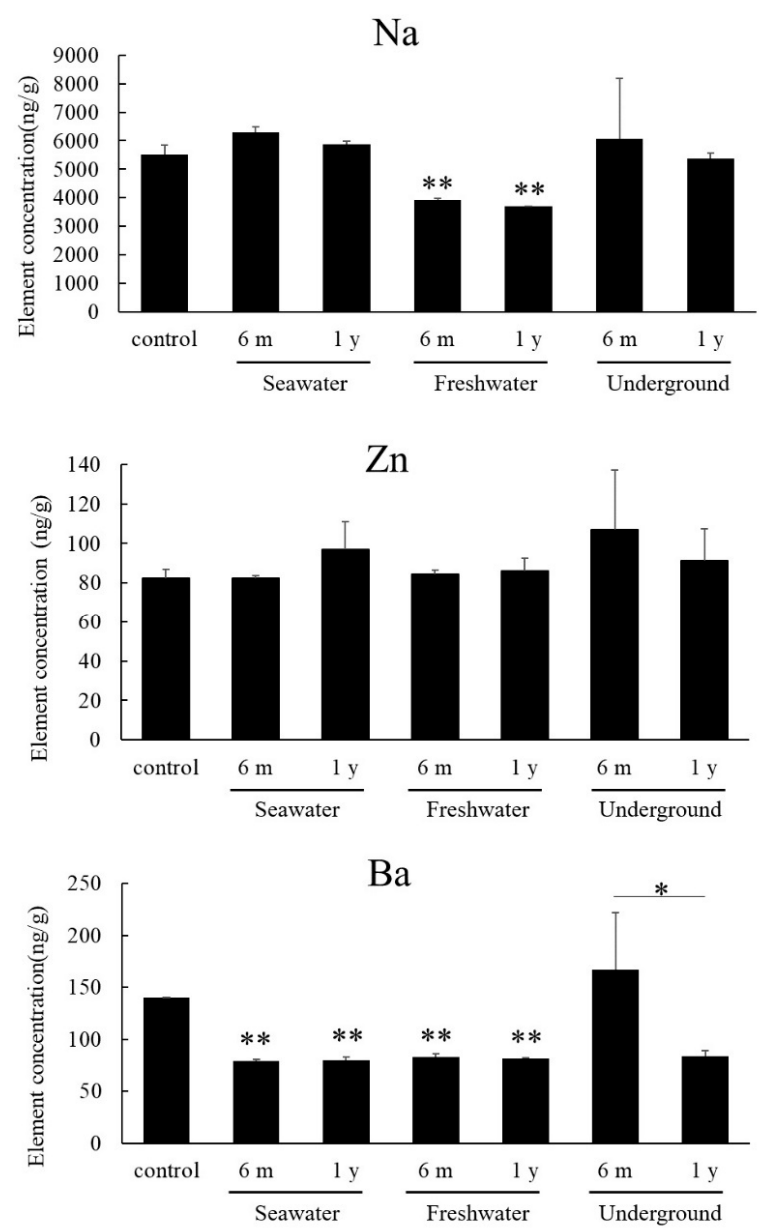

Figure 6. Quantitative analysis of $\mathrm{Na}, \mathrm{Zn}$, and $\mathrm{Ba}$ in the control and three environmental conditions by inductively coupled plasma optical emission spectroscopy (ICP-OES). Means and standard deviations are presented. ${ }^{*} p<0.05,{ }^{* *} p<0.01$ vs. control. 


\subsection{Bone Density}

In all conditions at 6 months and 1 year, micro X-ray CT $(n=5)$ showed the lamella structure and many small canals in the compact bone that are frequently observed in younger animals (Figure 7). The volume of each bone specimen was obtained from three-dimensional images, and bone density was calculated from the mass (Table 3). One sample for outdoor conditions at 1 year (Sample 1) was identified as an outlier and was, therefore, omitted from statistical analyses. Although the densities tended to decrease at 6 months and increase at 1 year, these changes were not statistically significant.

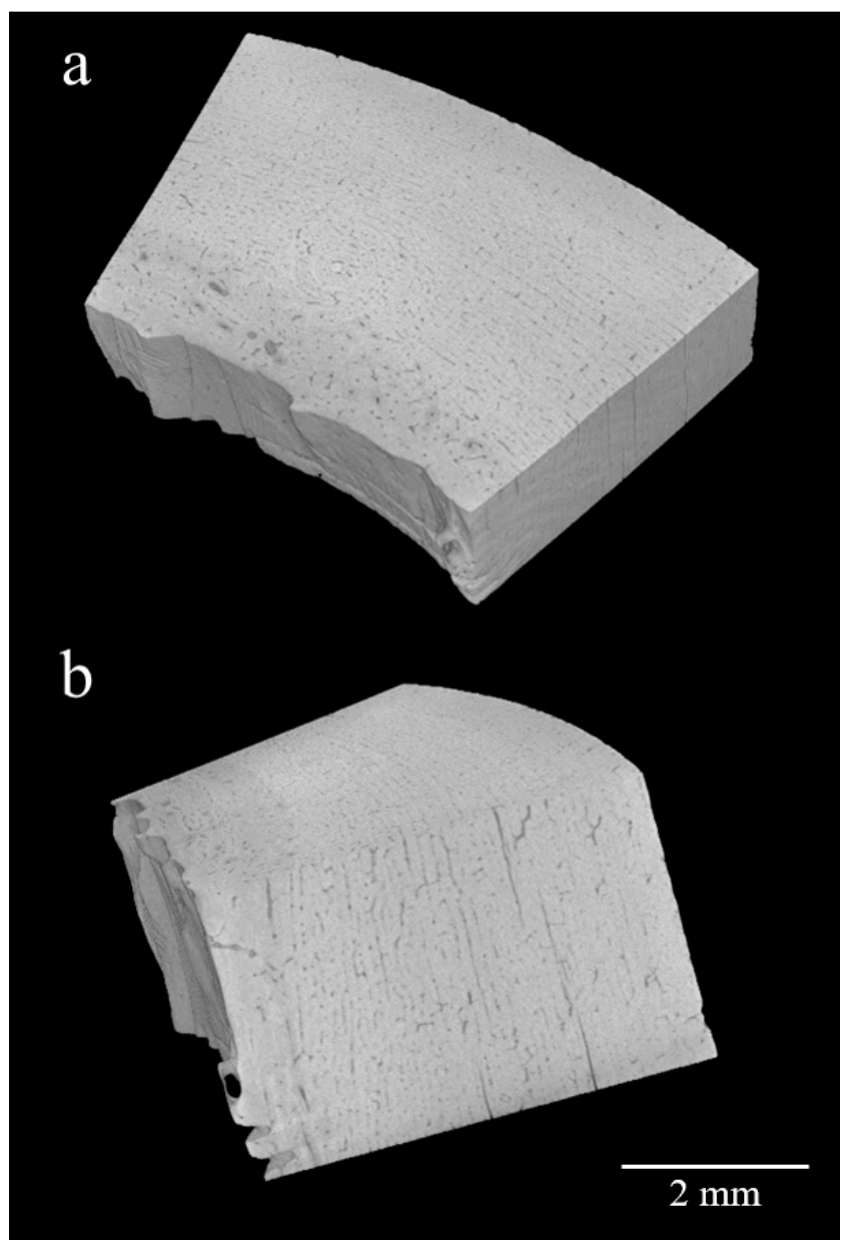

Figure 7. Three-dimensional (3D) images obtained by X-ray microcomputed tomography. The sample was maintained in freshwater for 1 year: (a) longitudinal direction; (b) minor axis direction.

Table 3. Bone density determined by X-ray microcomputed tomography.

\begin{tabular}{|c|c|c|c|c|c|c|c|c|c|c|c|}
\hline \multirow{2}{*}{ Sample No. } & \multicolumn{3}{|c|}{ Seawater } & \multicolumn{2}{|c|}{ Freshwater } & \multicolumn{2}{|c|}{ Underground } & \multicolumn{2}{|c|}{ Outdoors } & \multicolumn{2}{|c|}{ Indoors } \\
\hline & Control & $6 \mathrm{~m} *$ & $\mathbf{1} \mathbf{y}^{+}$ & $6 \mathrm{~m}$ & $1 y$ & $6 \mathrm{~m}$ & $1 \mathbf{y}$ & $6 \mathrm{~m}$ & $1 y$ & $6 \mathrm{~m}$ & $1 y$ \\
\hline Sample 1 & 1.864 & 1.972 & 2.060 & 2.026 & 1.997 & 1.934 & 1.981 & 1.995 & 2.444 & 2.005 & 2.040 \\
\hline Sample 2 & 1.717 & 1.929 & 2.020 & 1.965 & 2.079 & 1.961 & 2.042 & 1.984 & 1.985 & 2.018 & 2.054 \\
\hline Sample 3 & 2.089 & 2.006 & 2.089 & 2.056 & 2.029 & 2.010 & 2.021 & 2.041 & 2.057 & 2.053 & 2.035 \\
\hline Sample 4 & 2.162 & 2.027 & 2.048 & 2.027 & 2.072 & 2.002 & 2.003 & 2.003 & 2.004 & 2.045 & 2.026 \\
\hline Sample 5 & 2.542 & 1.981 & 2.045 & 2.027 & 2.056 & 1.973 & 1.988 & 1.996 & 1.995 & 2.008 & 2.062 \\
\hline Average & 2.075 & 1.983 & 2.053 & 2.020 & 2.047 & 1.976 & 2.007 & 2.004 & 2.097 & 2.026 & 2.043 \\
\hline SD & 0.316 & 0.037 & 0.025 & 0.033 & 0.034 & 0.031 & 0.025 & 0.022 & 0.196 & 0.022 & 0.015 \\
\hline
\end{tabular}




\section{Discussion}

Estimating the PMI of skeletal remains a major challenge in forensic science, with various techniques previously used, including IR/Raman microscopic imaging, ICP-OES, and radiocarbon dating $[1-3,7]$. Although these studies have provided valuable information, a reliable marker has not been established to estimate the PMI of skeletal remains. In the present study, we searched for effective indices for the accurate estimation of the PMI of bones. As a preliminary study, we evaluated the postmortem modifications after skeletonization on the basis of removing soft tissues and exposing the internal zone of bone. We investigated the change of bone as a function of DNA quantity, elemental composition, and bone density in bovine femurs experimentally exposed to five simulated conditions (seawater, freshwater, underground, outdoors, and indoors) for a maximum of 1 year. The DNA quantity decreased substantially in underground conditions after 3 days. The adsorption of DNA by soil makes extraction difficult, and this is a particular issue in the black soil unique to Japan [18]. In addition, PCR inhibitors in soil can affect the DNA quantity that measured by real-time PCR [20-22]. Furthermore, the quantity was significantly lower in the specimens maintained in freshwater and seawater. Cartozzo et al. [23] suggested that the greatest threat to DNA in bones submerged in water may be strand breakage resulting from hydrolysis (deamination, depurination, and depyrimidination). The decrease in DNA observed in this study may be due to this insult.

In addition to the PCR results for the $404 \mathrm{bp}$ product, we amplified a $128 \mathrm{bp}$ target to estimate the degree of DNA degradation. Lower amplification in the $404 \mathrm{bp}$ target was observed at the maximum of 3 months. This trend suggests that the real-time PCRs targeting differently sized targets could be an effective index for DNA degradation of short terms. As a factor contributing to degradation, the process for decalcification should be considered. We decalcified specimens by incubation with EDTA. Incubation protocols vary among studies [24,25]. We selected $24 \mathrm{~h}$ at $56^{\circ} \mathrm{C}$; relatively warm and long incubation conditions might affect DNA quality. Total DNA varied in amount with conditions and exposure periods. In this quantitation, exogenous DNA originated from microorganisms proliferating in bone and endogenous DNA of bone itself is quantitated at once regardless of the degree of DNA degradation. Exogenous DNA begins to increase in parallel with severe bone degradation over a long exposure period. The values of total DNA, therefore, depend on the valance between the amount of endogenous and exogenous DNA. Variations in increase and decrease observed in this short-term study must have been derived from this characteristic of quantitation. However, if an increase in total DNA is clearly observed in more highly degraded specimens, this quantitation can be used as an index for bone degradation. In addition, Sessa et al. [26] reported the influence of the insects in postmortem changes on bones. They mentioned that the presence of insects feeding on the marrow could be one of the reasons for the poor DNA quality; however, other factors such as the environmental conditions where the skeleton was found cannot be excluded. The results may support ours.

An ICP-OES analysis was performed to find effective elements for estimating the PMI of bone. In qualitative and semiquantitative analyses, $\mathrm{Na}, \mathrm{Zn}$, and Ba showed variation in concentration among the conditions. Thus, some elements can be used to estimate the PMI as shown in the previous report [3]. However, additional analyses with more time points at the initial stage are needed to clarify the relation between elements and the PMI.

No clear change in bone density was observed in this study. Longato et al. [9] suggested that specimens with a short PMI have higher bone densities compared with specimens with a long PMI according to a study using anthropological human bones. Delannoy et al. [27] suggested that there are significant differences in human bone mass loss between environments (indoors, soil indoors, soil outdoors, soil outdoors protected from rain). In the present study, we used bovine femurs. Aerssens et al. [28] reported that bone density varies depending on the type and part of bone, as well as among individuals. Differences in bone properties might explain differences in results between studies.

In the present study, we investigated various parameters for estimating the PMI of skeletal remains. We confirmed the usefulness of real-time PCR for determining the level of DNA degradation. In particular, the difference in amplification of the two PCR targets (404 bp and $128 \mathrm{bp}$ ) may be 
an effective index for estimating the PMI after 1-3 months. On the other hand, element concentrations determined by ICP-OES, particularly the concentrations of $\mathrm{Na}$ and $\mathrm{Ba}$, changed with respect to environmental conditions and time. However, additional analyses with more time points are needed to clarify the relationship between the elements and the PMI.

We admit that this study is a limited experimental research and not applicable to forensic cases as it is. In particular, we removed soft tissues prior to environmental exposure, which is not realistic in actual cases. Moreover, we did not perform a blind PMI evaluation according to the data obtained in this study. However, it might be said that this study is valuable for identifying the changes in bone after skeletonization. Further studies using more realistic specimens would bring more informative results for estimating the PMI. Regarding the result that bone density remained nearly unchanged in this study, it should be reinvestigated using pig or dog femurs, which are more similar to those of human.

Author Contributions: Conceptualization, M.N. and K.S.; methodology, M.N., K.I., Y.O., T.F. and M.U.; investigation, M.N.; writing-original draft preparation, M.N. and K.S.; supervision, K.U. All authors have read and agreed to the published version of the manuscript.

Funding: This work was partly supported by JSPS KAKENHI Grant Number 16H02688.

Conflicts of Interest: The authors declare no conflict of interest.

\section{References}

1. Creagh, D.; Cameron, A. Estimating the Post-Mortem Interval of skeletonized remains: The use of Infrared spectroscopy and Raman spectro-microscopy. Radiat. Phys. Chem. 2017, 137, 225-229. [CrossRef]

2. Woess, C.; Unterberger, S.H.; Roider, C.; Ritsch-Marte, M.; Pemberger, N.; Cemper-kiesslich, J.; Hatzer-Grubwieser, P.; Person, W.; Pallua, J.D. Assessing various Infrared (IR) microscopic imaging techniques for post-mortem interval evaluation of human skeletal remains. PLOS ONE 2017, 12, e0174552. [CrossRef] [PubMed]

3. Walden, S.J.; Mulville, J.; Rowlands, J.P.; Evans, S.L. An analysis of systematic elemental changes in decomposing bone. J. Forensic Sci. 2018, 63, 207-213. [CrossRef] [PubMed]

4. Le Garff, E.; Mesli, V.; Marchand, E.; Behal, H.; Demondion, X.; Becart, A.; Hedouin, V. Is bone analysis with $\mu$ CT useful for short postmortem interval estimation? Int. J. Legal Med. 2018, 132, 269-277. [CrossRef] [PubMed]

5. Akbulut, N.; Çetin, S.; Bilecenoğlu, B.; Altan, A.; Akbulut, S.; Ocak, M.; Orhan, M.K. The micro-CT evaluation of enamel-cement thickness, abrasion, and mineral density in teeth in the postmortem interval (PMI): New parameters for the determination of PMI. Int. J. Legal Med. 2020, 134, 645-653. [CrossRef]

6. Amadasi, A.; Cappella, A.; Cattaneo, C.; Cofrancesco, P.; Cucca, L.; Merli, D.; Milanese, C.; Pinto, A.; Profumo, A.; Scarpulla, V.; et al. Determination of the post mortem interval in skeletal remains by the comparative use of different physico-chemical methods: Are they reliable as an alternative to $14 \mathrm{C}$ ? HOMO 2017, 68, 213-221. [CrossRef]

7. Cappella, A.; Gibelli, D.; Muccino, E.; Scarpulla, V.; Cerutti, E.; Caruso, V.; Sguazza, E.; Mazzarelli, D.; Cattaneo, C. The comparative performance of PMI estimation in skeletal remains by three methods (C-14, luminol test and OHI): Analysis of 20 cases. Int. J. Legal Med. 2018, 132, 1215-1224. [CrossRef]

8. Sterzik, V.; Jung, T.; Jellinghaus, K.; Bohnert, M. Estimating the postmortem interval of human skeletal remains by analyzing their optical behavior. Int. J. Legal Med. 2016, 130, 1557-1566. [CrossRef]

9. Longato, S.; Wöss, C.; Hatzer-Grubwieser, P.; Bauer, C.; Parson, W.; Unterberger, S.H.; Kuhn, V.; Pemberger, N.; Pallua, A.K.; Recheis, W.; et al. Post-mortem interval estimation of human skeletal remains by micro-computed tomography, mid-infrared microscopic imaging and energy dispersive X-ray mapping. Anal. Methods 2015, 7, 2917-2927. [CrossRef]

10. Kaiser, C.; Bachmeier, B.; Conrad, C.; Nerlich, A.; Bratzke, H.; Eisenmenger, W.; Peschel, O. Molecular study of time dependent changes in DNA stability in soil buried skeletal residues. Forensic Sci. Int. 2008, 177, 32-36. [CrossRef] 
11. Mameli, A.; Piras, G.; Delogu, G. The Successful Recovery of Low Copy Number and Degraded DNA from Bones Exposed to Seawater Suitable for Generating a DNA STR Profile. J. Forensic Sci. 2014, 59, 470-473. [CrossRef] [PubMed]

12. Pérez-Martínez, C.; Pérez-Cárceles, M.D.; Legaz, I.; Prieto-Bonete, G.; Luna, A. Quantification of nitrogenous bases, DNA and collagen type I for the estimation of the postmortem interval in bone remains. Forensic Sci. Int. 2017, 281, 106-112. [CrossRef] [PubMed]

13. Johnson, L.A.; Ferris, J.A.J. Analysis of postmortem DNA degradation by single-cell gel electrophoresis. Forensic Sci. Int. 2002, 126, 43-47. [CrossRef]

14. Alaeddini, R.; Walsh, S.J.; Abbas, A. Forensic implications of genetic analyses from degraded DNA-A review. Forensic Sci. Int. Genet. 2010, 4, 148-157. [CrossRef]

15. Alaeddini, R. Forensic implications of PCR inhibition-A review. Forensic Sci. Int. Genet. 2012, 6, $297-305$. [CrossRef]

16. Samsuwan, J.; Somboonchokepisal, T.; Akaraputtiporn, T.; Srimuang, T.; Phuengsukdaeng, P.; Suwannarat, A.; Mutirangura, A.; Kitkumthorn, N. A method for extracting DNA from hard tissues for use in forensic identification. Biomed. Rep. 2018, 9, 433-438. [CrossRef] [PubMed]

17. Gallelo, G.; Kuligowski, J.; Pastor, A.; Diez, A.; Bernabeu, J. Chemical element levels as a methodological tool in forensic science. J. Forensic Res. 2014, 6, 1.

18. Miyaguchi, H.; Nakahara, H.; Sugita, R. Evaluation of the commercial kits for the extraction of extracellular DNA in soil. Jpn. J. Forensic Sci. Technol. 2019, 24, 63-72. [CrossRef]

19. Imaizumi, K.; Akutsu, T.; Miyasaka, S.; Yoshino, M. Development of species identification tests targeting 16S ribosomal RNA coding region in mitochondrial DNA. Int. J. Legal Med. 2007, 121, 184-191. [CrossRef] [PubMed]

20. Watson, R.J.; Blackwell, B. Purification and characterization of a common soil component which inhibits the polymerase chain reaction. Can. J. Microbiol. 2000, 46, 633-642. [CrossRef]

21. Braid, M.D.; Daniels, L.M.; Kitts, C.L. Removal of PCR inhibitors from soil DNA by chemical flocculation. J. Microbiol. Methods 2003, 52, 389-393. [CrossRef]

22. Imaizumi, K.; Miyasaka, S.; Yoshino, M. Quantitative analysis of amplifiable DNA in tissues exposed to various environments using competitive PCR assays. Sci. Justice 2004, 44, 199-208. [CrossRef]

23. Cartozzo, C.; Singh, B.; Boone, E.; Simmons, T. Evaluation of DNA Extraction Methods from Waterlogged Bones: A Pilot Study. J. Forensic Sci. 2018, 63, 1830-1835. [CrossRef] [PubMed]

24. Campos, P.F.; Craig, O.E.; Turner-Walker, G.; Peacock, E.; Willerslev, E.; Gilbert, M.T.P. Annals of Anatomy DNA in ancient bone-Where is it located and how should we extract it? Ann. Anat. 2012, 194, 7-16. [CrossRef] [PubMed]

25. Korlević, P.; Gerber, T.; Marie-Theres, G.; Hajdinjak, M.; Nagel, S.; Aximu-Petri, A.; Meyer, M. Reducing microbial and human contamination in DNA extractions from ancient bones and teeth. Biotechniques 2015, 93, 87-93. [CrossRef] [PubMed]

26. Sessa, F.; Varotto, E.; Salerno, M.; Vanin, S.; Bertozzi, G.; Galasi, F.M.; Maglietta, F.; Salerno, M.; Tuccia, F.; Pomara, C.; et al. First report of Heleomyzidae (Diptera) recovered from the inner cavity of an intact human femur. J. Forensic Legal Med. 2019, 66, 4-7. [CrossRef]

27. Delannoy, Y.; Colard, T.; Le, E.; Mesli, V.; Aubernon, C.; Penel, G.; Hedouin, V.; Gosset, D. Effects of the environment on bone mass: A human taphonomic study. Leg. Med. 2016, 20, 61-67. [CrossRef]

28. Aerssens, J.; Boonen, S.; Lowet, G.; Dequeker, J. Interspecies differences in bone composition, density, and quality: Potential implications for in vivo bone research. Endocrinology 1998, 139, 663-670. [CrossRef]

Publisher's Note: MDPI stays neutral with regard to jurisdictional claims in published maps and institutional affiliations. 